\title{
Lichens as biomonitors for organic air pollutants
}

\author{
Van der Wat L. ${ }^{a}$ and Forbes P.B.C.*a \\ ${ }^{a}$ Laboratory for Separation Science, Department of Chemistry, University of Pretoria, Private Bag \\ X20, Hatfield, 0028, South Africa. Email: lvanderwat@gmail.com; patricia.forbes@up.ac.za, +27 \\ 124205426 \\ *To whom correspondence should be directed
}

\begin{abstract}
Lichens are useful biomonitors for semi-volatile organic air pollutants, particularly polycyclic aromatic hydrocarbons (PAHs), as a result of their ability to respond to air pollutants at different levels, their slow growth rate, longevity and their ability to indicate the presence and concentrations of these pollutants. Consequently there has been a recent global trend in environmental analytical research to utilize lichens in this manner, where Soxhlet and ultrasonic assisted extraction are the most common analyte extraction techniques. A wide range of total PAH concentrations have been determined in lichens from different environments, although phenanthrene, fluoranthene, naphthalene and pyrene tend to dominate the PAH profiles, with higher 2- and 3-ring PAH concentrations than 6-ring compound concentrations. In order to facilitate inter-study comparisons, the development of a reproducible, sensitive analytical method for organic pollutants in lichens is needed.
\end{abstract}

\section{Keywords}

Air pollution, lichens, biomonitors, organic air pollutants, polycyclic aromatic hydrocarbons, polychlorinated dibenzo- $p$-dioxins, polychlorinated dibenzofurans, semi-volatile organic air pollutants

\begin{abstract}
Abbreviations
Ace: acenaphthylene, Ant: anthracene, BaA: benzo[a]anthracene, Chry: chrysene, DbA: dibenzo [a,h] anthracene, DAD/V-UV: diode array detector/ultravioletvisible detector, DSASE: dynamic sonication assisted solvent extraction, FluAn: fluoranthene, Flu: fluorine, FLD: fluorescence detector, GC-MS: gas chromatography-mass spectrometry, HpCDD: heptachlorodibenzo- $p$-dioxin, HPLC: high performance liquid chromatography, LOD: limit of detection, MW: molecular weight, Naph: naphthalene, OCDD: octachlorodibenzodioxin, OCDF: octachlorodibenzofuran, PeCDD: pentachlorodibenzo- $p$-dioxin, PeCDF: pentachlorodibenzofuran, Phe: phenanthrene, POPs: persistent organic pollutants, PAHs: polycyclic aromatic hydrocarbons, PCDD/Fs: polychlorinated dibenzo- $p$-dioxins and polychlorinated dibenzofurans, Pyr: pyrene, SPE: solid phase extraction, SVOC: semi-volatile organic compounds, TeCDF:

tetrachlorodibenzofuran
\end{abstract}

\section{Introduction}

Lichens are symbiotic organisms found on trees, rocks, in soils and even on 
weevils and giant Galapagos turtles [1]. They are perennial, resilient and are able to live for many years in extreme conditions - being found in locations from the icy Himalayas to deserts [2, 3]. The use of lichens as biomonitors comes as a result of the ability of lichens to respond to air pollutants at different levels, their slow growth rate, longevity and their ability to indicate the presence and concentrations of these pollutants $[4,5]$.

Lichens have the unusual capability towards the uptake of ions and substrates at concentrations beyond their needs. Metal ions are typically absorbed in a passive, extracellular manner and are bound reversibly by an ion exchange mechanism. It has been found that lichens are able to bind cadmium, lead, tin and zinc at higher concentrations than higher plants, even mosses [6]. It has been suggested that these trace elements are absorbed and stored by particulate entrapment as well as passive and active intracellular uptake in addition to ion exchange $[7,8]$. There are many factors that determine the absorption and release processes in the lichens, namely the chemical nature of the compound, the presence and influence of other compounds, the size of the particles to be absorbed, and the chemical composition of the particles [9].

One of the earliest successful uses of lichens as biomonitors was by Sloof et al [10] who studied the concentration of pollutants in lichens and compared it qualitatively with the atmospheric concentrations of suspended and deposited particulate matter. Sloof and Wolterbeek [9] performed some elemental analyses (including cobalt, scandium and zinc) on lichens and successfully related the determined concentrations with atmospheric concentrations. In addition, a ${ }^{137} \mathrm{Cs}$ study after the Chernobyl accident on both lichens and wet and dry depositions showed good correlations with dispersion model data sets [11]. It was consequently shown by Sloof [9] that elemental concentrations within lichens appear to equilibrate with the surrounding atmospheric concentration levels, which proved that lichens are suitable candidates for the biomonitoring of air pollution.

The absorption of atmospheric pollutants by lichens has consequently been a field of interest for many years, including the investigation into the uptake of sulphur dioxide by Hawksworth and Rose [12] as well as Rogers[13]. It is understood that lichens absorb pollutants (metals and organic air pollutants) by either wet deposition or dry deposition. The absence of a cuticular wax layer on lichens means that they are able to absorb pollutants much more easily than other higher plants.

The absorption of lead by lichens has been extensively studied due to the toxic nature of the heavy metal. An early application in this regard was a study by Garty, who used lichens as biomonitors to track the lead emissions from automobiles along highways [14]. Over the years, lichen biomonitoring research has been conducted into a range of inorganic analytes including mercury, most transition metals, radionuclides, fluoride, sulphur, nitrogen and acid rain, which all accumulate in the lichen thallus $[15,16,17,18,19,20]$.

More recently, the use of lichens as biomonitors for organic air pollutants has 
been investigated. Although lichens do not have a waxy cuticle or stomata, they do, however, produce and release lipid metabolites onto their surfaces which are suspected of behaving in a similar manner as the cuticle does in plants [21]. The lipophilic nature of the surface of lichens then readily attracts lipophilic compounds, such as atmospheric semi-volatile organic compounds (SVOCs), and facilitates their uptake, where their incorporation into cells would be metabolically controlled $[22,23]$.

Organic air pollutants are typically hydrophobic and this means that uptake tends toward dry deposition [24, 25]. Metal ions and other water-soluble compounds are deposited on the lichen surface by other mechanisms. Both hydrophobic and hydrophilic compounds can be assimilated by lichens as a result of the volatilization of compounds from soils - or by direct methods such as wind impaction or splashing from the ground during rainfall episodes $[26,27]$.

Here we review the current trend of using lichens as biomonitors of semi-volatile organic air pollutants, focusing on polycyclic aromatic hydrocarbons (PAHs) and persistent organic pollutants (POPs). POPs are typically chemicals that partition favorably to organic matter of a non-polar nature. They are either deliberately produced (for example agrochemicals) or form accidentally through processes like combustion (such as polychlorinated dibenzo- $p$-dioxins and polychlorinated dibenzofurans (PCDD/Fs)). They are known to have long half-lives and therefore accumulate in organic matter [28]. The associated health risks are often related to chronic exposure to POPs, and the effects of exposure include endocrine disruption as well as carcinogenic and mutagenic effects [29].

In this paper we discuss the use to date of lichens as biomonitors for semivolatile organic air pollutants (primarily PAHs), and we review the sample preparation and analytical techniques that have been employed in this regard. A comparison of the levels of organic pollutants found in lichens from different studies and geographical areas is also presented. For reviews on the progress made into biomonitoring of metal pollution using lichens, the reader is referred to references [30] and [31].

\section{Lichens as bioindicators and biomonitors of air pollution}

The lichen thallus is a complex symbiotic vegetative lower plant composed of two organisms: a fungus and an algae or cyanobacteria. The cell wall consists of a multilaminate and a granular layer. Adhering to the outside of the cells is a fibrous polysaccharide layer. The lichens hyphae can either orientate randomly or regularly in a parallel manner - these two types form the basic structure of the layers. The cortex (outer layer) of the lichen serves as a regulator for gas exchange and protective support of the lichen and it is in this layer that small gaps are found, allowing the soredia (the reproductive structures of lichens) to pass into the atmosphere. This layer is covered by an epicortex, which is a porous, non-cellular polysaccharide. It is believed that the porous nature of the epicortex is what enables efficient gas exchange [32]. Figure 1 shows a simplified illustration of a cross section of a foliose lichen. 


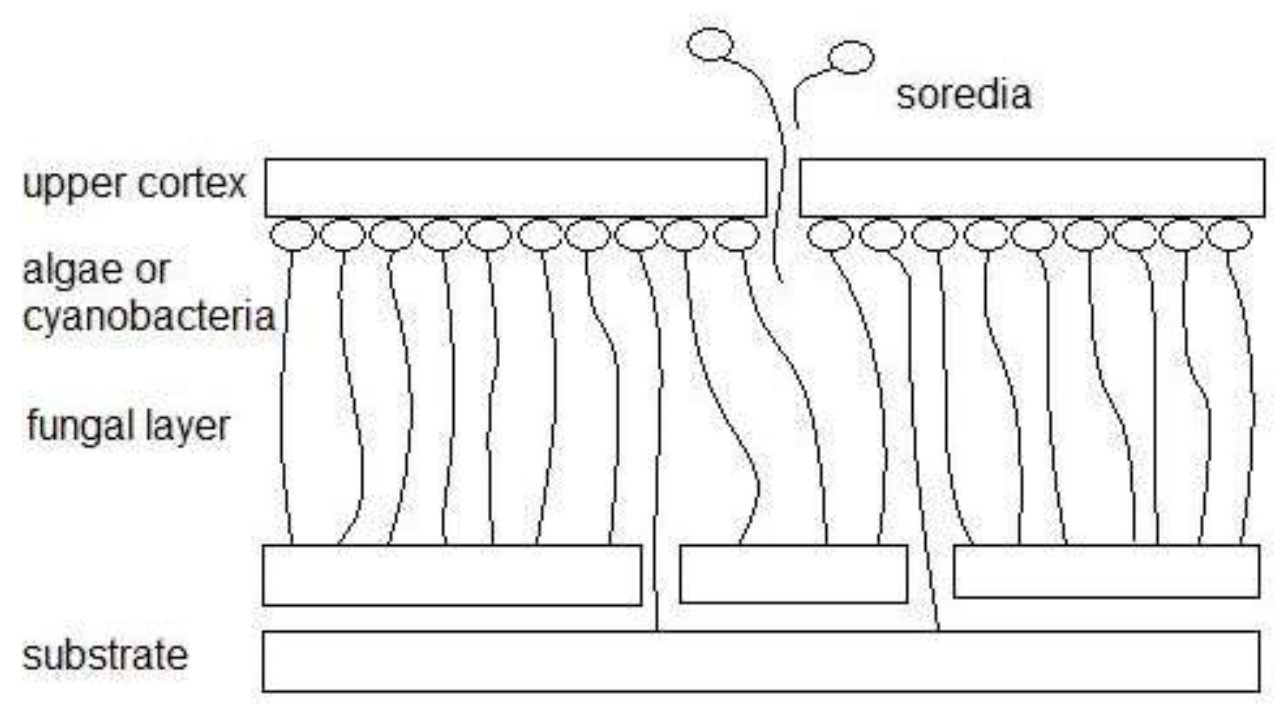

Figure 1: Simplified cross section through a foliose lichen 
There are three types of lichens: fruticose, foliose and crustose. The foliose lichens are known to have the highest surface area to dry weight ratio, and are said to accumulate airborne particles more readily than fruticose lichens [33]. The foliose lichens are completely exposed to ambient air as a result of having few points of attachment to the substrate. Fruticose lichens are flatter; a leaf like structure with defined upper and lower layers, subsequently only the upper layer is in contact with the ambient air. The crustose lichens are tightly attached to their substrates and are thus difficult to remove for analysis and are less exposed to the surrounds [21].

Lichens have been utilized to monitor air pollution in three different ways [30]: (i) to determine the concentration of specific pollutants accumulated in the thallus

(ii) to use the effect of pollution sources on the life span and presence or absence of lichen species to map out the distribution and effect of pollution in a specific area and

(iii) to take healthy lichens with little background pollutant accumulation and to transplant them into polluted areas to measure the accumulation of pollutants or the consequential degradation of the thallus.

When conducting an experiment that exploits the absorptive nature of compounds by lichens, the choice of lichen species is paramount to the success of the study. The choice must be made with the method of investigation in mind: if a lichen transplant is to be done, a species that is very sensitive to changes in pollution should be chosen, whereas a hardy local species should be used if the concentration of target analytes in the thallus is to be determined at a sampling site. It is important to identify the species of lichen to be studied as lichen species selectivity for absorption of compounds from the atmosphere has been illustrated by Blasco et al [34] for example.

A distinction between bioindicators and biomonitors has been made in the literature. Using lichens as bioindicators has, in the past, meant that the apparent health of a specific lichen species is tracked for changes in growth and proliferation (so called 'injury symptoms') to gauge the extent of pollution in the area. On the other hand, biomonitoring is a method to measure the response of lichens to air pollution exposure; meaning that the biomonitor should reflect an integrated exposure over time. For a few years, it was believed that lichens could not be used as biomonitors [35] because there was little understanding on how to extract the compounds of interest and which analytical methods to use for the analysis. Upon reviewing recent publications, the trend in research leans toward the use of lichens as biomonitors rather than bioindicators and will therefore be focused on in this paper.

\section{Biomonitoring of organic air pollutants using lichens}

Utilizing the accumulative nature of lichens is advantageous over direct air sampling because large volumes of air would need to be sampled for a long 
period of time (over 24 hours or more) to obtain detectable concentrations of trace-level organic air pollutants. Direct air sampling also only provides information on the current air quality. Lichens, on the other hand, accumulate the organic air pollutants, thus providing concentrations that are detectable using sensitive instrumentation, as well as an integrated value of the atmospheric organic pollutant levels. This is relevant when studying these pollutants because their associated health risks are often related to chronic exposure [29]. Another advantage of utilizing lichens is that it is a simple and cheap sampling method, applicable in locations that are less accessible with bulky equipment, such as the Pyrenees Mountains [36].

Investigations into the levels of PCDD/Fs and PAHs in lichens have been performed in countries including Portugal, Spain, Poland, Italy and India [37, 38, 39, 40, 41, 42, 43, 44, 45, 46, 47, 48]. A study by Augusto et al [48] showed that lichens are better accumulators of PAHs than soil and pine needles, whilst their PAH profiles are similar to that of the ambient air. Schrlau et al [45] also found that lichens were more effective at accumulating POPs than pine needles and mosses. It was shown in 2002 by Migaszewski et al that the lichen species studied had a higher PAH concentration than the host bark, and that the same lichen species had consistent PAH concentrations despite growing on different tree bark species [43].

Studies have been performed to identify which lichens are better at absorbing different organic air pollutants. It has been reported that the fruticose lichens absorb the low molecular weight POPs better, most likely due to their high surface area to volume ratio, whilst the foliose lichens preferentially absorb the higher molecular weight organic pollutants [34, 45, 46, 47]. Despite these differences, it has been found that similar POP profiles have emerged from studies, where 2- to 4-ringed PAHs are primarily observed in PAH studies with lichens $[36,37,38,42,43,44,48,49,50]$ and the PCDD/F profiles show a tendency towards TeCDD/PeCDD and PeCDF domination [39, 41, 46, 51]. Blasco et al [34] investigated the behavior of different lichen species under the same conditions with regard to their abilities to accumulate PAHs. It was generally found that there was a high 3-ring PAH content and a low 6-ring PAH content across all species, as has been found in other studies [38]. Phenanthrene, closely followed by naphthalene, fluoranthene and benzo[a] anthracene are often the PAHs occurring at the highest concentrations in lichens [34, 48] (refer to Table 3).

Studies have also indicated that the substrate from which the lichens are collected may play a role in the accumulation of POPs and other compounds [52]. It is unlikely that any POPs are assimilated via bark due to their hydrophobic nature, so the main mechanisms of uptake are due to dry deposition as well as from the soil, as described in section 1 . Bauer et al $[53,54]$ showed that the heavier POPs diffuse slower than the lower molecular weight POPs, and that the higher MW POPs are thus more likely associated with particles that remain on the surface of lichens. It has been shown by Augusto et al [55] that the PCDD/F concentrations remain relatively constant after periods of wet conditions (rain or fog, for example) suggesting that some POPs are retained within the lichen 
thallus and are not rinsed off easily. A parallel study for PAHs has not yet been published, but studies of other organic air pollutants strongly suggest that a similar trend for PAH integration in lichens is to be expected $[56,57]$.

\section{Experimental procedures employed in the analysis of semi-volatile organic pollutants in lichens}

\subsection{Sampling}

Two distinctly different sampling methods are used when lichens are to be utilized as tools for air pollution monitoring. The technique of transplanting lichens from relatively clean environments to areas of interest has been a popular method when studying heavy metals $[58,59]$ but is not readily applied to PAH studies, due to the long term exposure to the low levels of these pollutants, which is required in order to allow for meaningful and detectable results.

Direct sampling, on the other hand, is a popular sampling technique which exploits the fact that lichens accumulate pollutants with time directly from the atmosphere. Lichens are mostly sampled at heights of more than $1 \mathrm{~m}$ above the ground except for Migasewski et al [43] who sampled from as low as $25 \mathrm{~cm}$ above the ground. Such low sampling heights may influence results due to contamination of the lichens by soil, as well as protection of the lichens from wind by surrounding shrubs and rocks at the base of a tree. In contrast, Augusto et al [41] sampled lichens off roof tiles for a study into atmospheric dioxin and furan deposition in Portugal.

When atmospheric furans and dioxins have been studied using lichens, the samples have been removed from the substrates, placed in either glass jars [60] or stored in plastic bags [41], dried at room temperature and then stored for analysis. For PAH studies, the sampling methodology varies; whereas some groups sample the lichens into amber vials $[43,48,57,61]$, others sample into paper bags [37], wrap samples in aluminum foil [38] or polyester barrier film bags [45]. Due to the fact that PAHs may photodegrade, the sampling and storage procedures that prevent further chemical changes to the lichen after sampling are most regularly employed. Non-permeable collection containers are also preferable, in order to prevent loss of the more volatile analytes (2- and 3-ring PAHs).

Whereas some studies have meticulously reported sampling conditions, such as avoiding the sampling of fruiting lobes and only sampling the apical lobes of lichen structures [37], most studies collect samples of the same species from different tree species $[43,48]$, which could increase uncertainty when comparing studies, since different tree species would have different bark and canopy structures, potentially protecting some lichen species better than others from wind and atmospheric deposition.

Augusto et al $[57,61]$ showed that seasonal flux influences the concentration of PAHs in lichen samples, with the highest concentrations of PAHs found in lichens 
sampled during the wet winter months, and the lowest concentrations during the warmer, dry summer months. This may be as a result of increased evaporation of organic air pollutants; an increase in emissions during the cold winter months, or as a result of UV induced photodegradation or other photochemical reactions that may take place $[62,63,64]$. It is for this reason that it is important that the season when lichen sampling took place is reported for consistency and to allow for comparison.

Other conditions that need to be considered when sampling are wind speed and direction (laminar boundary will be affected by air flow), air pressure (an increased pressure will mean a higher concentration of compounds in the atmosphere thus higher accumulation rates) as well as humidity [21, 34, 57, 65]. For a summary of necessary factors to consider when using lichens as biomonitors for POPs, the reader is referred to a review by Augusto et al [55].

\subsection{Sample preparation techniques}

Once the lichens have been sampled, an extraction process is selected to remove and concentrate the organic analytes from the sample matrix. Traditionally, Soxhlet extraction has been employed for the extraction of both PAHs and PCDD/Fs [38, 39, 40, 46]. Table 1 shows the common experimental conditions when using Soxhlet, which is currently less popular due to its high solvent and energy consumption requirements and time required for efficient extraction. Migaswewski et al [43] used a modified Soxhlet technique, Soxtec, for PAH extractions, using dichloromethane. Although it performed successfully as one of the first PAH studies using lichens as biomonitors, this method has not been applied in any other similar studies reported to date, which is likely due to the move towards greener chemistry practice utilizing methods which are faster and use less energy and lower solvent volumes.

Pressurized liquid extraction (PLE) has been employed by Schrlau et al [45] on lichens followed by a silica-based SPE cleanup in the analysis of certain pesticides and PAHs in the USA. A mass of $2.0 \mathrm{~g}$ lichen was extracted using dichloromethane as the solvent at $100^{\circ} \mathrm{C}$ for 5 minutes. A comparative study between PLE and other extraction methods for PAHs in lichens does not appear in literature, however Ratola et al [67] performed PLE on pine needles in a PAH study, but found that ultrasonic extraction was the most successful technique, over PLE and Soxhlet.

Ultrasound assisted solvent extraction techniques are commonly used due to the fact that smaller sample sizes can be accommodated, less solvents are used, and the extractions are relatively fast [44, 50]. Whereas Guidotti et al $[44,49]$ used cyclohexane as the solvent for ultrasound assisted extraction, combining only 2 extractions, Domeno et al [50] extracted a $0.2 \mathrm{~g}$ lichen sample using portions of $15 \mathrm{~mL}$ dichloromethane each in four subsequent extractions. A study in which a novel ultrasonic assisted extraction technique for lichens was developed by Domeno and Blasco [50], found that hexane is the solvent which extracts most PAHs efficiently and the new DSASE technique has been popular in numerous 
Table 1: Reported experimental conditions for lichen sample preparation using Soxhlet extraction

\begin{tabular}{|l|l|l|l|l|l|}
\hline $\begin{array}{l}\text { Analyte } \\
\text { studied }\end{array}$ & $\begin{array}{l}\text { Mass } \\
\text { lichen } \\
\text { sample } \\
\text { used } \\
\text { (g) }\end{array}$ & Solvent scheme & $\begin{array}{l}\text { Solvent } \\
\text { volume }\end{array}$ & $\begin{array}{l}\text { Extraction } \\
\text { time }\end{array}$ & Reference \\
\hline PCDD/Fs & 10 & $\begin{array}{l}\text { Methylene } \\
\text { chloride:hexane } \\
(1: 1)\end{array}$ & Not reported & $\begin{array}{l}18-24 \\
\text { hours }\end{array}$ & {$[39,41]$} \\
\hline PAHs & 2 & Dichloromethane & $100 \mathrm{ml}$ & 16 hours & $\begin{array}{l}{[38,66,} \\
69,70]\end{array}$ \\
\hline PAHs & 2 & Acetonitrile & $200 \mathrm{ml}$ & 24 hours & $\begin{array}{l}{[47,48,} \\
62]\end{array}$ \\
\hline PAHs & 0.2 & Dichloromethane & $250 \mathrm{ml}$ & 6 hours & {$[50]$} \\
\hline PAHs & $0.6-$ & $\begin{array}{l}\text { Hexane: acetone } \\
(1: 1)\end{array}$ & $150 \mathrm{ml}$ & 2 hours & {$[37]$} \\
\hline
\end{tabular}

aRefers to EPA 1613B method

bRefers to an Automated Soxhlet extraction and reflects total extraction time of the extraction in solvent and the reflux in the rinse position

Table 2: Reported sample clean up conditions for lichen extracts

\begin{tabular}{|c|c|c|c|c|}
\hline $\begin{array}{l}\text { Analyte } \\
\text { studied }\end{array}$ & $\begin{array}{l}\text { Type of clean } \\
\text { up }\end{array}$ & $\begin{array}{l}\text { Sorbent } \\
\text { Type }\end{array}$ & Elution solvent & Reference \\
\hline $\mathrm{PCDD} / \mathrm{Fs}$ & $\begin{array}{l}\text { Column and gel } \\
\text { chromatography }\end{array}$ & $\begin{array}{l}\text { Column: } \\
\text { Mixed } \\
\text { silica \& } \\
\text { aluminium } \\
\text { oxide } \\
\text { Gel: Bio } \\
\text { Beads S- } \\
\text { X3A }\end{array}$ & Not reported & {$[41,46]$} \\
\hline PAHs & $\begin{array}{l}\text { Column } \\
\text { chromatography }\end{array}$ & Silica & $\begin{array}{l}25 \text { ml methylene } \\
\text { chloride:pentane }(2: 3)\end{array}$ & $\begin{array}{l}{[38,44,} \\
69,70]\end{array}$ \\
\hline PAHs & $\begin{array}{l}\text { Column } \\
\text { chromatography }\end{array}$ & Silica & $50 \mathrm{ml}$ dichloromethane & [45] \\
\hline PAHs & $\begin{array}{l}\text { Column } \\
\text { chromatography }\end{array}$ & Florisil & $30 \mathrm{ml}$ acetonitrile & {$[47,48]$} \\
\hline PAHs & $\begin{array}{l}\text { Solid phase } \\
\text { extraction }\end{array}$ & $\begin{array}{l}\text { Normal } \\
\text { phase - } \\
\mathrm{NH}_{2}\end{array}$ & $\begin{array}{l}2 \mathrm{ml} \\
\text { hexane:dichloromethane } \\
(65: 35)\end{array}$ & $\begin{array}{l}{[34,36} \\
37,68]\end{array}$ \\
\hline
\end{tabular}


studies since $[34,42,68]$. The method has grown in popularity because it is a fast method that uses less solvent and energy, with satisfactory results.

With regards to the clean up of sample extracts, either column chromatography or solid phase extraction is commonly used and these are summarized in Table 2. Silicon column chromatography has been employed extensively, with different solvent schemes. A direct comparison between the results of these studies is a challenge as a result of the different affinities solvents have for different PAHs [50], leading to biased elutions. The volume of sorbent beds is not clearly defined in most studies, which also influences the extent to which the analytes are recovered. More recently, solid phase extraction has been used to clean up the lichen extracts with mainly normal phase $-\mathrm{NH}_{2}$ columns being used after a study by Blasco et al [68] found that these columns, combined with an elution solvent of hexane dichloromethane $(65: 35)$ yielded the best recoveries. This method has not been reviewed since 2007, despite the production of many new sorbents, of which a few are PAH specific. Due to the importance of sample preparation in delivering accurate and reliable analytical results, the extraction methodology as well as sample clean up techniques employed should be continually revised and optimised as new techniques become available, to enhance analyte recoveries and reproducibility of results.

\subsection{Analytical techniques}

When analyzing lichen extracts for PCDD/Fs and PAHs, the main analytical techniques used are HPLC using reverse phase C18 columns and gas chromatography, using a variety of column configurations. Augusto et al $[48,57]$ made use of a HPLC coupled to an ultraviolet fluorescence detector (FLD) as well as an ultraviolet/visible detector (DAD/V-UV), which had the advantage of sensitivity as a result of the fluorescence detector with detection limits of 58 ng.g-1 reported for the sum of all 16 EPA Priority PAHs. Selectivity, as a result of using the DAD/V-UV detector, operating at $254 \mathrm{~nm}$ ensured well-resolved peaks, depending on chromatographic optimization. Likewise, Shukla and Upreti also used HPLC coupled to a UV detector $[38,40,69,70]$ with reported detection limits as low as 8 ng.g-1.

In studies with the explicit focus on PCDD/F content in lichens, high resolution gas chromatography coupled to high resolution mass spectrometry is used so that dioxins and furans can be efficiently separated and accurately identified [41, $46,60]$. The use of a DB dioxin column $[41,46]$ has been found to further improve resolution of PCDD/Fs and should be used where possible. When conducting PAH studies, Migaszewski et al [43], Domeno et al as well as Blasco et al [34] have used a GC-MS for analysis, reporting detection limits as low as 21 ng.g-1 [50]. The use of Rxi-5Sil MS, HP 5-MS and factor four VF5-MS columns is common due to the non-polar nature of these capillary columns resulting in good separation of PAHs, but run times ranging between 29 minutes [34] and 81 minutes [37] are reported. Sacrificing peak separation, particularly of the benzofluoranthenes, as well as BaA and Chry for the sake of faster run times should be avoided to ensure an accurate representation of the PAH profile, owing to the different toxicities of PAH compounds. 
Table 3: Summary of results from reported PAH studies using lichens as biomonitors

\begin{tabular}{|c|c|c|c|c|c|c|c|c|c|}
\hline $\begin{array}{l}\text { Most Common } \\
\text { PAHs }\end{array}$ & Location & Year & Lichen Species & $\begin{array}{l}\text { Sample } \\
\text { mass used } \\
\text { (g) }\end{array}$ & $\begin{array}{l}\text { Extraction } \\
\text { Method }\end{array}$ & $\begin{array}{l}\text { Analysis } \\
\text { Method }\end{array}$ & LOD & $\begin{array}{l}\text { Total PAH } \\
\text { concentration } \\
\text { detected }\end{array}$ & Reference \\
\hline $\begin{array}{l}\text { Phe, Ant, Pyr, } \\
\text { FluAn }\end{array}$ & $\begin{array}{l}\text { Dolomites, } \\
\text { Italy }\end{array}$ & 2014 & $\begin{array}{l}\text { Pseudevernia } \\
\text { furfuracea (L.) Zopf }\end{array}$ & $0.6-0.8$ & $\begin{array}{l}\text { Automated } \\
\text { Soxhlet } \\
\text { Extraction }\end{array}$ & GC-MS & - & 758.0 ng.g-1 & 37 \\
\hline Phe, Pyr, FluAn & $\begin{array}{l}\text { Sines, } \\
\text { Portugal }\end{array}$ & 2010 & P. hypoleucinum & 2 & Soxhlet & $\begin{array}{l}\text { HPLC- } \\
\text { FLD- } \\
\text { DAD/V- } \\
\text { UV }\end{array}$ & - & 95.5-873.8ng.g-1 & 48 \\
\hline 3- and 4-ring & $\begin{array}{l}\text { Sines, } \\
\text { Portugal }\end{array}$ & 2009 & $\begin{array}{l}\text { Parmotrema } \\
\text { hypoleucinum } \\
\text { (Steiner) Hale }\end{array}$ & 2 & Soxhlet & $\begin{array}{l}\text { HPLC- } \\
\text { FLD- } \\
\text { DAD/V- } \\
\text { UV }\end{array}$ & - & 93.56-599.24ng.g-1 & 47 \\
\hline $\begin{array}{l}\text { 2-, 3- and 4- } \\
\text { ring }\end{array}$ & $\begin{array}{l}\text { Sines, } \\
\text { Portugal }\end{array}$ & 2013 & $\begin{array}{l}\text { Parmotrema } \\
\text { hypoleucinum } \\
\text { (Steiner) Hale }\end{array}$ & 2 & Soxhlet & $\begin{array}{l}\text { HPLC- } \\
\text { FLD- } \\
\text { DAD/V- } \\
\text { UV }\end{array}$ & - & 58-536ng.g-1 & 55 \\
\hline 4 ring & $\begin{array}{l}\text { South } \\
\text { Central } \\
\text { Poland }\end{array}$ & 2002 & $\begin{array}{l}\text { Hypogymnia } \\
\text { physodes }\end{array}$ & - & $\begin{array}{l}\text { Soxtec } \\
\text { liquid-solid } \\
\text { extraction }\end{array}$ & GC-MS & - & $3-1887$ ppb & 43 \\
\hline $\begin{array}{l}\text { Naph, Ace, Phe, } \\
\text { Pyr, FluAn, }\end{array}$ & $\begin{array}{l}\text { Aragon } \\
\text { Valley, } \\
\text { Spain } \\
\end{array}$ & 2007 & Parmelia sulcata & 0.2 & DSASE & GC-MS & - & 352-1654ng.g-1 & 68 \\
\hline $\begin{array}{l}\text { Naph, Phe, } \\
\text { FluAn }\end{array}$ & $\begin{array}{l}\text { Pyrenees, } \\
\text { Spain }\end{array}$ & 2008 & Evernia prunastri & 0.2 & DSASE & GC-MS & - & 692-6420ng.g-1 & 36 \\
\hline $\begin{array}{l}\text { Naph, Phe, } \\
\text { FluAn }\end{array}$ & $\begin{array}{l}\text { Somport } \\
\text { Tunnel, } \\
\text { Spain } \\
\end{array}$ & 2006 & Parmelia sulcata & 0.2 & DSASE & GC-MS & - & $0.91-1.92$ ug.g- ${ }^{-1}$ & 42 \\
\hline
\end{tabular}




\begin{tabular}{|c|c|c|c|c|c|c|c|c|c|}
\hline $\begin{array}{l}\text { Naph, Phe, } \\
\text { FluAn, BaA }\end{array}$ & $\begin{array}{l}\text { Pyrenees, } \\
\text { Spain }\end{array}$ & 2011 & $\begin{array}{l}\text { P. sulcata, } E . \\
\text { prunastri, } R . \\
\text { farinacea, } P . \\
\text { furfuracea, Usnea sp. } \\
\text { and } \text { L. pulmonaria }\end{array}$ & 0.2 & DSASE & GC-MS & - & 238-6240ng.g-1 & 34 \\
\hline Flu, BaA, DbA, & $\begin{array}{l}\text { Zaragoza } \\
\text { City, Spain }\end{array}$ & 2006 & Xanthoria parietina & 0.2 & DSASE & GC-MS & $\begin{array}{l}0.021- \\
0.032 \text { ug. } \\
g^{-1}\end{array}$ & +/- 330ng.g-1 & 50 \\
\hline Ace, Phe & $\begin{array}{l}\text { Kanpur } \\
\text { City, India }\end{array}$ & 2012 & $\begin{array}{l}\text { R. sophodes (Ach.) } \\
\text { Massal }\end{array}$ & 2 & Soxhlet & $\begin{array}{l}\text { HPLC-V- } \\
\text { UV }\end{array}$ & $\begin{array}{l}0.008- \\
0.050 \mathrm{ug} . \\
\mathrm{g}^{-1}\end{array}$ & 0.189-0.494ug.g-1 & 40 \\
\hline Ace, Phe, Pyr & $\begin{array}{l}\text { Dehra Dun, } \\
\text { Himalayas }\end{array}$ & 2009 & $\begin{array}{l}\text { Phaeophyscia } \\
\text { hispidula }\end{array}$ & 2 & Soxhlet & $\begin{array}{l}\text { HPLC-V- } \\
\text { UV }\end{array}$ & $\begin{array}{l}10- \\
30 \mathrm{ppt}\end{array}$ & 3.38-25.0ug.g ${ }^{-1}$ & 38 \\
\hline $\begin{array}{l}\text { Ace, Phe, } \\
\text { FluAn, }\end{array}$ & $\begin{array}{l}\text { Haridwar, } \\
\text { India }\end{array}$ & 2012 & Pyxine subcinerea & 2 & Soxhlet & $\begin{array}{l}\text { HPLC-V- } \\
\text { UV }\end{array}$ & $\begin{array}{l}10- \\
\text { 30ng.L-1 }\end{array}$ & 1.25-187.3ug.g-1 & 70 \\
\hline Mixed & $\begin{array}{l}\text { Himalayas, } \\
\text { India }\end{array}$ & 2013 & \begin{tabular}{|l|} 
Dermatocarpon \\
vellereum Zschacke
\end{tabular} & 2 & Soxhlet & $\begin{array}{l}\text { HPLC-V- } \\
\text { UV }\end{array}$ & $\begin{array}{l}\text { 10- } \\
\text { 30ng.L-1 }\end{array}$ & $0.136-4.96 u g . g^{-1}$ & 69 \\
\hline Phe, Ant, FluAn & Rieti, Italy & 2003 & $\begin{array}{l}\text { Pseudevernia } \\
\text { furfuracea }\end{array}$ & 2 & UASE & GC-MS & $\begin{array}{l}0.5- \\
3.6 \mathrm{ug} . \mathrm{kg} \\
-1-\end{array}$ & 56-159ug.kg-1 & $44^{\mathrm{b}}$ \\
\hline Pyr, FluAn & $\begin{array}{l}\text { Viterbo, } \\
\text { Italy }\end{array}$ & 2009 & $\begin{array}{l}\text { Pseudevernia } \\
\text { furfuracea }\end{array}$ & 2 & UASE & GC-MS & $\begin{array}{l}0.01- \\
0.03 \text { ug.g } \\
-1\end{array}$ & 168.0-395.0ng.g ${ }^{-1}$ & $49^{\mathrm{b}}$ \\
\hline
\end{tabular}

a PAHs are abbreviated as follows: Fluoranthene (FluAn), pyrene (Pyr), phenanthrene (Phe), dibenzo (a, h)anthracene (DbA), benzo(a)anthracene (BaA), anthracene (Ant), naphthalene (Naph), acenaphthylene (Ace) and fluorene (Flu).

$\mathrm{b}$ These studies were lichen transplant studies. 


\section{Levels of PAHs and PCDD/Fs found in lichens}

Polycyclic aromatic hydrocarbons (PAHs), which are by-products of combustion processes, are receiving significant attention in environmental science research, due to their inclusion in the Convention on Long-Range Transboundary Air Pollution Protocol [71], as well as due to the carcinogenic potential of some PAHs, such as benzo(a)pyrene, dibenzo[a, h]anthracene and the benzo fluoranthenes [72, 73, 74]. A number of studies have therefore been conducted to determine the PAH content of lichens in different environments, as summarized in Table 3.

PAH concentration ratios found in lichens may also be used for source apportionment studies. For example: phenanthrene/anthracene (Phe/Ant) and fluorene/pyrene (Flu/Pyr) [50] may be employed where a Phe/Ant ratio higher than 10 and Flu/Pyr ratios higher than 1 indicate a mix of pyrogenic and petrogenic sources $[34,47]$. Another popular application of the concentration data is to look at the toxicity equivalents (TEFs) as detailed by Nisbet and Lagoy [75], where the product of the concentration of a specific PAH and its toxicity compared to benzo[a]pyrene gives an indication of the extent to which the specific PAH contributes to the carcinogenic potency [57]. The number of rings in the PAH structures are also often compared to give an indication of the PAH profiles that the lichens are accumulating: generally increased toxicity is related to an increase in number of rings.

Domeno et al [50] found total PAH concentrations of around 340 ng. g $^{-1}$ using their dynamic sonication assisted solvent extraction (DSASE) technique, in lichens which were sampled near a river outside of a city in Spain, whereas a study by the same group, using the same technique found total PAH concentrations of between $1.2-1.65$ ug.g- $^{-1}$ in lichens in an area with a high density of traffic. Using the diagnostic ratios, it was suggested that the traffic was indeed the main contributor towards the high PAH content in the lichens [42]. These studies have successfully exploited the efficacy of lichens as biomonitors to diagnose pollution sources of specific SVOCs. The large variation in total PAH concentration is heavily influenced not only by the contributing pollution sources at the location, but by many environmental factors such as the seasons in which sampling was undertaken, the altitude at which samples were collected and the extraction techniques used in the laboratory.

When comparing the results of the studies presented in Table 3 , it is evident that phenanthrene, fluoranthene, naphthalene and pyrene tend to dominate the PAH profiles, with higher 2- and 3-ring PAH concentrations than 6-ring compound concentrations $[34,36,38,42,48,68]$. This is possibly due to the fact that the heavier PAHs are less volatile and are generally associated with particulate matter and are less airborne in their nature.

The vast range in total PAH concentrations can be illustrated by the difference between the study by Shukla et al [70] where concentrations as high as 187.3 ug. $\mathrm{g}^{-1}$ were detected, compared to 0.058 ug.g $^{-1}$ total PAH concentration detected 
Table 4: Summary of results from reported PCDD/F studies using lichens as biomonitors

\begin{tabular}{|c|c|c|c|c|c|c|c|}
\hline $\begin{array}{l}\text { Most } \\
\text { Common } \\
\text { PCDD/Fs }\end{array}$ & Location & Year & $\begin{array}{l}\text { Lichen } \\
\text { Species }\end{array}$ & Extraction Method & Analysis Method & $\begin{array}{l}\text { Total PCDD/Fs concentration } \\
\text { detected }\end{array}$ & Reference \\
\hline $\begin{array}{l}\text { TeCDF, } \\
\text { PeCDF }\end{array}$ & $\begin{array}{l}\text { Setubal } \\
\text { Peninsula } \\
\text { Portugal }\end{array}$ & 2004 & $\begin{array}{l}\text { Xanthoria } \\
\text { Parientina }\end{array}$ & Solvent Extraction & GC-HRMS & $427.74 \mathrm{ng} / \mathrm{kg}$ & 41 \\
\hline $\begin{array}{l}\text { TeCDF, } \\
\text { PeCDF, } \\
\text { PeCDD }\end{array}$ & $\begin{array}{l}\text { Setubal } \\
\text { Peninsula } \\
\text { Portugal }\end{array}$ & 2007 & $\begin{array}{l}\text { Xanthoria } \\
\text { Parientina }\end{array}$ & Soxhlet & HRGC/HRMS & 197.5-1218.7 ng/kg d.w. & 39 \\
\hline $\begin{array}{l}\text { OCDD, OCDF, } \\
\text { HpCDD in X. } \\
\text { parientina } \\
\text { and less } \\
\text { chlorinated } \\
\text { in R. } \\
\text { canariensis }\end{array}$ & $\begin{array}{l}\text { Setubal } \\
\text { Peninsula } \\
\text { Portugal }\end{array}$ & . & $\begin{array}{l}\text { Xanthoria } \\
\text { Parientina and } \\
\text { Ramalina } \\
\text { canariensis } \\
\text { Steiner }\end{array}$ & Soxhlet & HRGC/HRMS & $170.8-1058.6 \mathrm{ng} / \mathrm{kg}$ & 45 \\
\hline
\end{tabular}


by Augusto et al [57] in Portugal. In India, the samples were taken in an industrial area close to the Himalayas and in Portugal the samples were taken in an industrial area on the coast. Shukla et al [70] used Soxhlet in their sample preparation, whilst the sample preparation technique was not reported for the study in Portugal.

Few studies using lichens as biomonitors for PCDD/Fs have been undertaken, as summarized in Table $4[39,41,46]$. The specificity of the lichen species towards furan and dioxin uptake is illustrated clearly in the study by Augusto et al [46] and highlights the importance of consistency in sampling strategies. The profiles of PCDD/Fs contained in lichens vary between different species, such that $X$. parientina contained a higher number of chlorinated pollutants such as OCDD, OCDF and HpCDD when compared to $R$. canariensis, which accumulated the lesser chlorinated furans and dioxins [46]. The concentrations detected varied between industrial, urban, agricultural and forested areas, but it was suggested that lichens accumulate PCDD/Fs at higher concentrations than other biomonitors such as pine needles and mosses [41]. It was furthermore shown that the PCDD/F content in lichens was similar to that of the soil, without any soil particle contamination [41]. More studies in different regions need to be undertaken to better understand the potential application of lichens as biomonitors for PCDD/Fs in forming a global understanding of atmospheric PCDD/Fs levels.

There is generally a lack of reporting limits of detection (LODs) and analyte recoveries in the reported studies, which makes the comparison of techniques difficult, since laboratories cannot directly compare their findings to others if analytical parameters are not evident. Little mention is made of replicate analyses and variation within bulk samples. Large differences in analyte concentrations are seen within studies and in addition to differences in sampling environments, this could be due in part to a lack of homogeneity within samples. Lichens are perennial and grow continually, resulting in a difference in organic pollutant concentration across the thallus as the lichen grows and integrates airborne pollutants, which would in turn affect the homogeneity of the lichen samples. This needs to be remembered when interpreting the results.

\section{Conclusions and future trends}

Lichens are useful biomonitors for semi-volatile organic air pollutants, particularly PAHs, as a result of their ability to respond to air pollutants at different levels, their slow growth rate, longevity and their ability to indicate the presence and concentrations of these pollutants. Consequently there has been a recent global trend in environmental analytical research to utilize lichens in this manner.

An area which requires further research regarding lichens as biomonitors for organic air pollutants, is the determination of relationships between the concentration of pollutants found in the lichens and atmospheric levels thereof, which has only recently begun to be addressed [57]. The understanding that 
environmental factors such as humidity, altitude and wind direction affect the amount of organic air pollutants retained by lichens is also starting to influence how results are interpreted [55], which should improve comparisons between different samples across continents. The importance of sample homogeneity must also be emphasized.

Despite the fact that many PAH extraction techniques have been established, there is scope for the development of quicker techniques, which are greener with higher recoveries. In terms of the analysis of sample extracts, several new products designed specifically for PAH analysis, such as SPE cartridges and GC columns, have been recently developed, which should assist in improving selectivity and sensitivity. Establishing a method that is reproducible and sensitive would improve the understanding of the organic pollutant levels in air globally, as this would facilitate comparison of results between studies.

A full understanding of the organic pollutant levels in our global atmosphere can only be reached once gaps in the global use of lichens as biomonitors are filled in. This would facilitate the development of a global distribution map of these atmospheric pollutants, which would allow for the identification of potential hotspots of pollution, which is an important step in the process of developing environmental protection and management policies.

\section{Acknowledgments}

The authors hereby acknowledge the generous financial support of the National Research Foundation (NRF) of South Africa.

\section{References}

[1] M. E. Hale, The Biology of Lichens, 2nd ed. London: Edward Arnold, 1974.

[2] L. Bergamaschi, E. Rizzio, G. Giaveri, A. Profumo, S. Loppi, M. Gallorini, Determination of baseline element composition of lichens using samples from high elevations, Chemosphere, 55 (2004) 933-939.

[3] K.W. Maphangwa, C.F. Musil, L. Raitt, L. Zedda, Differential interception and evaporation of fog, dew and water vapour and elemental accumulation by lichens explain their relative abundance in a coastal desert, J. Arid Environ., 82 (2012) 7180.

[4] J. E. Sloof, M. de Bruin, and H. Wolterbeek, Critical evaluation of some commonly used biological monitors for havy metal air pollution, in Environmental Contamination: Proceedings of the international Conference Venice (Italy), Edinburgh (1988) 296-298.

[5] P. L. Nimis, M. Castello, and M. Perotti, Lichens as bioindicators of heavy metal pollution: a case study at La Spezzia (Italy), in Plants as Biomonitors, Indicators for Heavy Metals in the Terrestrial Environment, B. Markert, Ed. New York: VHC, 1993, 265-284.

[6] Y. Tuominen and T. Jaakkola, Absorption and accumulation of mineral elements and radioactive nuclides, in The Lichens, V. Ahmadjian and Hale M. E., Eds. London: Academic Press (1974) 185-223.

[7] D. H. S. Richardson and E. Nieboer, Lichens and pollution monitoring, Endeavor, 5 
(1981) 127-133.

[8] G. Tyler, Uptake, retention and toxicity of heavy metals in lichens. A brief review, Water, Air, Soil Pollut., 47 (1989) 321-333.

[9] J. E. Sloof, Lichens as quantitative biomonitors for atmospheric trace-element deposition, using transplants, Atmos. Environ., 29 (1995) 11-20.

[10] J. E. Sloof and H Wolterbeek, National trace element air pollution monitoring survey using epiphytic lichens, Lichenologist, 23 (1991) 139-165.

[11] J. E. Sloof and H. Wolterbeek, Lichens as biomonitors for radiocesium following the Chernobyl accident, J Environ. Radioact., 16 (1992) 229-242.

[12] D. L. Hawksworth and F. Rose, Qualitative scale for estimating sulphur dioxide air pollution in England and Wales using epiphytic lichens, Nature, 227 (1970) 145148.

[13] R. W. Rogers, The 'city effect' on lichens in the Brisbane area, Search, 8 (1977) 7577.

[14] J. Garty, M. Galun, C. Fuchs, and N. Zisapel, Heavy metals in the lichen Caloplaca aurantia from urban, suburban and rural regions in Israel (a comparative study), Water, Air, Soil Pollut, 8 (1977) 171-188.

[15] K. J. Puckett, Bryophytes and lichens as monitors of metal deposition., Bibl. Lichenology, 30 (1988) 231-267.

[16] J. Garty, Lichens as biomonitors of heavy metal pollution, in Plants as Biomonitors: Indicators for Heavy Metals in the Terrestrial Environment, B. Markert, Ed. New York: VCH (1993) 193-257.

[17] S. Gombert, J. Asta, and M. R. D. Seaward, Correlation between the nitrogen concentration of two epiphytic lichens and the traffic density in an urban area, Environ. Pollut., 123 (2003) 281-290.

[18] Z. Jeran, T. Mrak, R. Jacimovic, F. Bati, D. Kastelec, R. Mavsar, P. Simonic, Epiphytic lichens as biomonitors of atmospheric pollution in Slovenian forests, Environ. Pollut., 146 (2007) 324-331.

[19] P.B.C. Forbes, M. Thanjekwayo, J.O. Okonkwo, M. Sekhula, and C. Zvinowanda, Lichens as biomonitors for manganese and lead in Pretoria, South Africa, Fresenius Environ. Bull., 18 (2009) 609-614.

[20] A. True, N. Panichev, J. Okonkwo, and P.B.C. Forbes, Determination of the mercury content of lichens and comparison to atmospheric mercury levels in the South African Highveld region., Clean Air J., 21 (2012) 19-25.

[21] I. Oksanen, Ecological and biotechnological aspects of lichens, Appl. Microbiol. Biotechnol., 73 (2006) 723-734.

[22] C. Branquinho, F. Catarino, D. Brown, M. J. Pereira, and A. Soares, Improving the use of lichens as biomonitors of atmospheric metal pollution, Sci. Total Environ., 232 (1999) 67-77.

[23] C. Branquinho, Lichens, in Metals in the Environment: Analysis by Biodiversity, M. N. V. Prasad, Ed. New York: Marcel Dekker (2001) 117-158.

[24] J. C. Duinker and F. Bouchertall, On the distribution of atmospheric polychlorinated biphenyl congeners between vapour phase, aerosols and rain, Environ. Sci. Technol., 23 (1989) 57-62.

[25] M. S. McLachlan and M. Horstmann, Forests as filters of airborne organic pollutants, Environ. Sci. Technol., 32 (1998) 413-420.

[26] S. Trapp and M. Matthies, Modeling volatilization of PCDD/F from soil and uptake into vegetation, Environ. Sci. Technol., 31 (1997) 71-74.

[27] K. C. Jones and R. Duarte-Davidson, Transfer of airborne PCDD/Fs to bulk 
deposition collectors and herbage, Environ, Sci. Technol., 31 (1997) 2937-2943.

[28] K. C. Jones and P. de Voogt, Persistent organic pollutants (POPs): state of the science, Environ. Pollut., 100 (1999) 209-221.

[29] M. Kogevinas, Human health effects of dioxin: cancer, reproductive and endocrine system effects, Hum. Reprod. Update, 7 (2001) 331-339.

[30] J. Garty, Biomonitoring atmospheric heavy metals with lichens: theory and application, Crit. Rev. Plant Sci., 20 (2001) 309-371.

[31] M.E. Conti and G. Cecchetti, Biological monitoring: lichens as bioindicators of air pollution assessment - a review, Environ Pollut., 114 (2001)471-492.

[32] M. E. Hale, Lichen structure viewed with the scanning electron microscope, in Lichenology: Progress and Problems, D. H. Brown, D. L. Hawksworth, and Bailey R. H., Eds. London: Academic Press (1976) 1-15.

[33] E. Nieboer, D. H. S. Richardson, and F. D. Tomassini, Mineral uptake and release by lichens: an overview, Bryologist, 81 (1978) 226-246.

[34] M. Blasco, C. Domeno, P. Lopez, and C. Nerin, Behaviour of different lichen species as biomonitors of air pollution by PAHs in natural ecosystems, J Environ Monit, 13 (2011) 2588-2596.

[35] L. L. Sigal, The relationship of lichens and bryophyte research to regulatory decisions in the United States, in Lichens, Bryophytes and Air Quality, T. H. Nash and V. Wirth, Eds. Berlin: Cramer (1988) 269-287.

[36] M. Blasco, C. Domeño, and C. Nerín, Lichen biomonitoring as feasible methodology to assess air pollution in natural ecosystems: combined study of quantitative PAHs analyses and lichen biodiversity in the Pyrenees Mountains, Anal. Bioanal. Chem., 391 (2008) 759-771.

[37] J. Nascimbene, M. Tretiach, F. Corana, F. Lo Schiavo, D. Kodnik, M. Dainese, B. Mannucci, Patterns of traffic polycyclic aromatic hydrocarbon pollution in mountain areas can be revealed by lichen biomonitoring: A case study in the Dolomites (Eastern Italian Alps), Sci. Tot. Environ., 475 (2014) 90-96.

[38] V. Shukla and D.K. Upreti, Polycyclic aromatic hydrocarbon (PAH) accumulation in lichen Phaeophyscia hispidula of DehraDun City, Garhwal Himalayas, Environ. Monit. Assess., 149 (2009) 1-7.

[39] S. Augusto, C. Máguas, F. Catarino, and C. Branquinho, Interpreting the dioxin and furan profiles in the lichen Ramalina canariensis Steiner for monitoring air pollution, Sci. Total Environ., 377 (2007) 114-123.

[40] Satya, D.K. Upreti, D.K Patel, Rinodina sophodes (Ach.) Massal.: a bioaccumulator of polycyclic aromatic hydrocarbons (PAHs) in Kanpur City, India, Environ. Monit. Assess., 184 (2012) 229-238.

[41] S. Augusto et al., Atmospheric dioxin and furan deposition in relation to land-use and other pollutants: a survey with lichens, J. Atmos. Chem., 49 (2004) 53-65.

[42] M. Blasco, C. Domeño, and C. Nerín, "Use of lichens as pollution biomonitors in remote areas: comparison of PAHs extracted from lichens and atmospheric particles sampled in and around the Somport tunnel (Pyrenees)," Environ. Sci. Technol., vol. 40, pp. 6384-6391, 2006.

[43] Z. M. Migaszewski, A. Galuszka, and P. Paslawski, Polynuclear aromatic hydrocarbons, phenols, and trace metals in selected soil profiles and plant bioindicators in the Holy Cross Mountains, South-Central Poland, Environ. Int., 28 (2002) 303-313.

[44] M. Guidotti, D. Stella, M. Owczarek, A. de Marco, and C. de Simona, Lichens as polycyclic aromatic hydrocarbons bioaccumulators used in atmospheric pollution 
studies, J. Chrom. A, 985 (2003) 185-190.

[45] J.E. Schrlau, L. Geiser, K.J. Hageman, D.H. Landers, S.M. Simonich, Comparison of lichen, conifer needles, passive air sampling devices, and snowpack as passive sampling media to measure semi-volatile organic compounds in remote atmospheres., Environ. Sci. Technol., 41 (2011) 10354-10361.

[46] S. Augusto, C. Máguas, and C. Branquinho, Understanding the performance of different lichen species as biomonitors of atmospheric dioxins and furans: potential for intercalibration, Ecotoxicology, 18 (2009) 1036-1042.

[47] S. Augusto, C. Maguas, J. Matos, M. J. Pereira, A. Soares and C. Branquinho, Spatial modeling of PAHs in lichens for fingerprinting of multisource atmospheric pollution, Environ. Sci. Technol., 43 (2009) 7762-7769.

[48] S. Augusto, C. Maguas, J. Matos, M. J. Pereira, and C. Branquinho, Lichens as an integrating tool for monitoring PAH atmospheric deposition: A comparison with soil, air and pine needles, Environ. Pollut., 158 (2010) 483-489.

[49] M. Guidotti et al., Monitoring of traffic-related pollution in a province of central Italy with transplanted lichen Pseudevernia furfuracea, Bull. Environ. Contam. Toxicol., 83 (2009) 852-858.

[50] C. Domeño, M. Blasco, C. Sánchez, and C. Nerín, A fast extraction technique for extracting polycyclic aromatic hydrocarbons (PAHs) from lichen samples used as biomonitors of air pollution: dynamic sonication versus other methods, Anal. Chim. Acta, 569 (2006) 103-112.

[51] S. Augusto, M. J. Pereira, A. Soares, and C. Branquinho, The contribution of environmental biomonitoring with lichens to assess human exposure to dioxins, Int. J. of Hyg. Environ. Health, 210, (2007) 433-438.

[52] J. E. Sloof and B. Wolterbeek, Substrate influence on epiphytic lichens, Environ. Monit. Assess., 25 (1993) 225-234.

[53] P. Bauer, A. Buchholz, and J. Schönherr, Diffusion in plant cuticles as affected by temperature and size of organic solutes: similarity and diversity among species, Plant, Cell Environ., 20 (1997) 982-994.

[54] H. Bauer and J. Schönherr, Determination of mobilities of organic compounds in plant cuticles and correlation with molar volumes, Pestic. Sci., 35 (1992) 1-11.

[55] S. Augusto, C. Maguas, and C. Branquinho, Guidelines for biomonitoring persistent organic pollutants (POPs), using lichens and aquatic mosses, Environ. Pollut., 180 (2013) 330-338.

[56] H. Kylin and H. Bouwman, Hydration State of the Moss Hylocomium splendens and the Lichen Cladina stellaris Governs Uptake and Revolatilization of Airborne $\alpha$ - and $\gamma$-Hexachlorocyclohexane, Environ. Sci. Technol., 46 (2012) 10982-10989.

[57] S. Augusto, M. J. Pereira, C. Maguas, and C. Branquinho, A step towards the use of biomonitors as estimators of atmospheric PAHs for regulatory purposes, Chemosphere, 92 (2013) 626-632.

[58] V. Cercasov, A. Pantelica, M. Salagean, G. Caniglia, and A. Scarlat, Comparitive study of the suitability of three lichen species to trace element air monitoring, Environ. Pollut., 119 (2002) 129-139.

[59] G. Caniglia, I. Calliari, L. Celin, and A. M. Tollardo, Metal determination by EDXRF in lichens: a contribution to pollutants monitoring, in Biological Trace Element Research, G.N. Schrauzer, Ed. Totowa, NJ: Humana Press Incorporated (1994) 213221. 
[60] S. Denys, D. Gombert, K. Tack, Combined approaches to determine the impact of wood fire on PCDD/F and PCB contamination in the environment: A case study, Chemosphere, 88 (2012) 806-812.

[61] S. Augusto, M.J. Pereira, C. Máguas, and C. Branquinho, Assessing human exposure to PAHs in a petrochemical region based on data from environmental biomonitors, J. Toxicol Environ. Health, 75 (2012) 1-10.

[62] C. Schauer, R. Niessner, and U. Pöschl, Polycyclic aromatic hydrocarbons in urban air particulate matter: decadal and seasonal trends, chemical degradation, and sampling artifacts, Environ. Sci. Technol., 37 (2003) 2861-2868.

[63] A. Beyer, F. Wania, T. Gouin, D. Mackay, and M. Matthies, Temperature dependence of the characteristic travel distance, Environ. Sci. Technol., 37 (2003) 766-771.

[64] K.H. Jung, M.M. Patel, R.L. Miller et al., Effects of heating season on residential indoor and outdoor polycyclic aromatic hydrocarbons, black carbon, and particulate matter in an urban birth cohort, Atmos. Environ., 44 (2010) 4545-4552.

[65] M. Bakker, J. Tolls, C. Kollöffel, Persistent, bioaccumulative and toxic chemicals I: fate and exposure, in American Chemical Society Symposium Series, (Chapter 16), R.L. Lipnick et al., Eds. (2000) 28-236.

[66] R. Bajpai, N. Karakoti, D.K. Upreti, Performance of a naturally growing Parmelioid lichen Remototrachyna awasthii against organic and inorganic pollutants, Environ Sci Pollut Res., 20 (2013) 5577-5592.

[67] N. Ratola, S. Lacorte, A. Alves, and D. Barcelo, Analysis of polycyclic aromatic hydrocarbons in pine needles by gas chromatography-mass spectrometry: Comparison of different extraction and clean up procedures, J. Chrom. A, 1114, (2006) 198-204.

[68] M. Blasco, C. Domeno, K. Bentayeb, and C. Nerín, Solid-phase extraction clean-up procedure for the analysis of PAHs in lichens, Int. J. Environ. Anal. Chem., 87 (2007) 833-846.

[69] V. Shukla and D.K. Upreti, Lichens reveal air PAH fractionation in the Himalaya, Environ. Chem. Lett., 11 (2013) 19-23.

[70] V. Shukla, D.K. Patel, D.K. Upreti, M. Yunus, Lichens to distinguish urban from industrial PAHs, Environ. Chem. Lett., 10 (2012) 159-16.

[71] Executive Body of the United Nations Economic Commission for Europe. (2009, December) United Nations Economic Commission for Europe. [Online]. Available at:

http://www.unece.org/fileadmin/DAM/env/lrtap/full\%20text/1998.POPs.e.pdf Last accessed: 20 May 2014

[72] L. Blaha, P. Kapplova, J. Vondracek, B. Upham, M. Machala, Inhibition of gapjunctional intercellular communication by environmentally occurring polycyclic aromatic hydrocarbons, Toxicol. Sci.,65 (2002) 43-51.

[73] A. Pullman and B. Pullman, "Electronic structure and carcinogenic activity of aromatic molecules: new developments," Adv. Cancer Res., 3 (1955) 117-169.

[74] G. Mastrangelo, E. Fadda, V. Marzia,Polycyclic aromatic hydrocarbons and cancer in man., Environ. Health Perspect., 104 (1996) 1166-1170.

[75] I. C. T. Nisbet and P. K. Lagoy, Toxic equivalency factors (TEFs) for polycyclic aromatic hydrocarbons (PAHs), Regul. Toxicol. Pharmacol., 16 (1992) 290-300. 